\title{
FOREIGN COMMUNICATIVE COMPETENCE AS A FACTOR OF PERSONAL DEVELOPMENT
}

\author{
Liudmyla Serdiuk \\ Kostiuk Institute of Psychology of National Academy of Pedagogical Sciences of Ukraine, \\ Kyiv, Ukraine \\ Olena Chykhantsova \\ Kostiuk Institute of Psychology of National Academy of Pedagogical Sciences of Ukraine, \\ Kyiv, Ukraine \\ Ingrida Baranauskiene \\ Klaipeda University, Klaipėda, Lithuania
}

\begin{abstract}
Life in Ukraine has provided people with diversity and possibility in communication with the corresponding increase in intercultural communication. Therefore, foreign language teaching and learning at the universities should not only be instrumental, but it should set a new goal to train students with intercultural communicative competence to meet the needs of our globalized world.

The article deals with the role of foreign language communicative competence and the problem of forming foreign language skills in communication that influence on the development of the person in the process of education in higher education institutions. Communicative competence means having 'a competence to communicate'. The aim of the article is to investigate the level of foreign language communicative competence of the individuals and its impact on personality development. We used such research methods as observation, interview and questionnaire, analysis of the results of communication and teaching of students in a foreign language, the author's method of determining the level of foreign language mastering, the expert assessments method. The results of our study determined that communicative competence implies the appropriate skills, the formation of which is a prerequisite for learning a foreign language in the educational environment.

The results of the experiment allowed us to establish the psychological specificity of the process of mastering a foreign communication. The communicative competence is considered as a factor of personal development in the process of effective mastering of foreign languages. The foreign communicative competence is a recent notion and there is no clear consensus about what it is. Sometimes this term is referred to as global competence, international competence, multicultural competence and so forth.
\end{abstract}

Keywords: development, foreign communicative competence, personal development.

\section{Introduction}

The 21st century was marked by significant changes in the socio-economic development of Ukraine. The country's international relations have become much 
stronger and its authority in the world and the European space has increased (Kozyreva, Sagaidak-Nikituk, \& Demchenko, 2017). Today, when Ukraine focusing on Europe, foreign language skills and intercultural communicative competence are one of the conditions for a person's personal and professional development. Knowledge of languages is an important prerequisite for the formation of personal, cultural and professional personality traits (Byram, Gribkova, \& Starkey, 2002). The overall strategy for the study of foreign languages is determined by the needs of modern society and the level of development of linguistic, psychological, pedagogical and related sciences. The basis of these sciences is the communicative approach, which determines the practical purpose of learning foreign languages, namely mastering foreign communication through the formation and development of communicative competence, which also involves the development of personality.

The effectiveness of language formation is a consequence of a number of psychological and pedagogical factors. These factors can be defined as significant circumstances that affect the success of personal communication. Success factors are based on the structure of educational activity, which allows them to be identified with its structural components of creating conditions for the development of internal motivation for communication, improving the educational process by including the individual in the process of discussing specific situations.

Therefore, foreign communication is essential to the development of the human psyche, formation and establishment of a rational, cultural behavior. Human mental development begins with communication. This is the first type of the social activity that arises in ontogeny and through which an individual receives the information necessary for its development. Thus, the foreign communication forms and develops abilities and acts as a means of acquiring knowledge and skills of the personality.

The aim of the article is to investigate the level of foreign language communicative competence of the individuals and its impact on students' development. To achieve the aim of the article we set out the following tasks: 1) to investigate the foreign communicative competence as a major factor in the development of the foreign language and 2) to identify the influence of the foreign language communicative competence on the process of personality's development.

\section{Literature review}

Many scientists have studied the problem of foreign language communication in the process of learning a foreign language (Chykhantsova, 2014; Chykhantsova, 2019; Drăghicescua, Cristeab, Petrescua, Gorghiuc, \& 
Gorghiud, 2015; Harmer, 2012; Menke \& Paesani, 2019; Petrie \& Avery, 2011; Boretska, 2010; Volobueva, 2012). Recently, the problem of improving the foreign language training of future specialists has become particularly relevant in Ukraine and has become the subject of many researches. Particularly, the psychological aspects of the formation of communicative competence have been studied by many researches (Tomchuk \& Buchatska, 2010). The problem of mastering a person in a foreign language in Ukraine was covered in a number of scientific works by L. Onufrieva (Onufrieva \& Onufrieva, 2010). The learning a foreign language takes on a personal meaning, depending on what kind of activity integrates the acquired language skills (Chykhantsova, 2014; Saenko, 2010).

The researcher R. Feuerstein (Feuerstein, Feuerstein, Falik, \& Rand, 2006) revealed the qualities that ensure successful mastery of a foreign language by personality: understanding of the importance of educational tasks for himself/herself and his/her future; mastering the strategy of further self-studying; the desire to work on the solution of educational tasks; sense of competence, ability to solve tasks; ability to control the behavior and activities; ability to set a real goal, plan ways to achieve it; the need and ability to meet the challenges of life, to learn; awareness of the need and availability of changes in the qualities, levels of training; confidence in the ability to make positive changes, to successfully solve problems; the willingness and ability to participate in teamwork.

The scientists view 'competence' as an evaluative category in psychopedagogical literature (Drăghicescua et al., 2015). This category characterizes a person as a subject of a particular activity and ensures success. This competence evaluates such components as the structure of knowledge and skills, value orientations, attitudes to the activity, its effectiveness and ability to improve it (Bolster \& Balandier-Brown, 2004; Menke \& Paesani, 2019). So, the communicative competence is an integrative personality formation that has a complex structure and acts as an interaction and interpenetration of linguistic, sociocultural competences, the level of formation of which enables a person to effectively carry out foreign language, interlinguistic, intercultural and interpersonal communication (Chykhantsova, 2014; Menke \& Paesani, 2019; Tomchuk \& Buchatska, 2010).

So, the foreign language communicative competence directly acts as a factor in the intellectual development of the personality. Individuals exchange and enrich information, acquire new interests, motives, goals of activity in the process of communication. They also acquire interpersonal interaction, the development of a general outlook, the formation of personal characteristics and character (Serdiuk, 2018). 


\section{Methodology}

The study involved 84 students of different specialties of the second and the third courses of the College 'Education' of the University 'Ukrain', Kiev, Ukraine: 35 men and 49 women. The age of respondents are from 18 to 20 years old. We processed the results of the survey using a computer program for statistical processing of data SPSS Statistics 21.0.

We used a set of research methods to diagnose communicative competence and the level of students foreign language masterying: 1) observation; 2) methods of oral (interview) and written (questionnaire) interviewing; 3) analysis of the results of communication and teaching of students in a foreign language; 4) the author's method of determining the level of foreign language masterying; 5) the expert assessments method.

Expert assessment of the level of development of the communicative component as a factor of development of students' foreign language communication was carried out by experts among the experienced foreign language teachers of the University 'Ukraine'. The assessment of foreign language communication skills of students included a set of tasks for identifying skills in listening, reading, speaking and writing.

\section{Research results}

We have developed the authorial structural model of foreign language communicative competence as a basis for determining a system of exercises and tasks that can provide the formation of a particular competence in a person as a macro object and its structural components (Fig. 1) (Chykhantsova, 2019). Under 'a foreign language' we understand a language originally from another country than the speaker. It is also a language not spoken in the native country of the person. We tested respondents' communicative competence as a factor of personal development through mastering a foreign language in the college. All of students in our research study English as the foreign language.

For our research we tested grammatical and lexical skills of students, ability to construct grammatically and lexically correct sentences, which should be clear to the interlocutor using Educational programs of foreign languages ([EPFL], 2017) and Ukrainian English language teacher learning platform ([UELTLP], 2020). We also tested intercultural communicative knowledge of topics that covered different aspects of personal relationships. During the reading and listening we tested the students' general understanding of the foreign texts, text's structure, the recognition of the links between parts of the text, the selective finding of special or necessary information in texts of various characters (EPFL, 2017). 


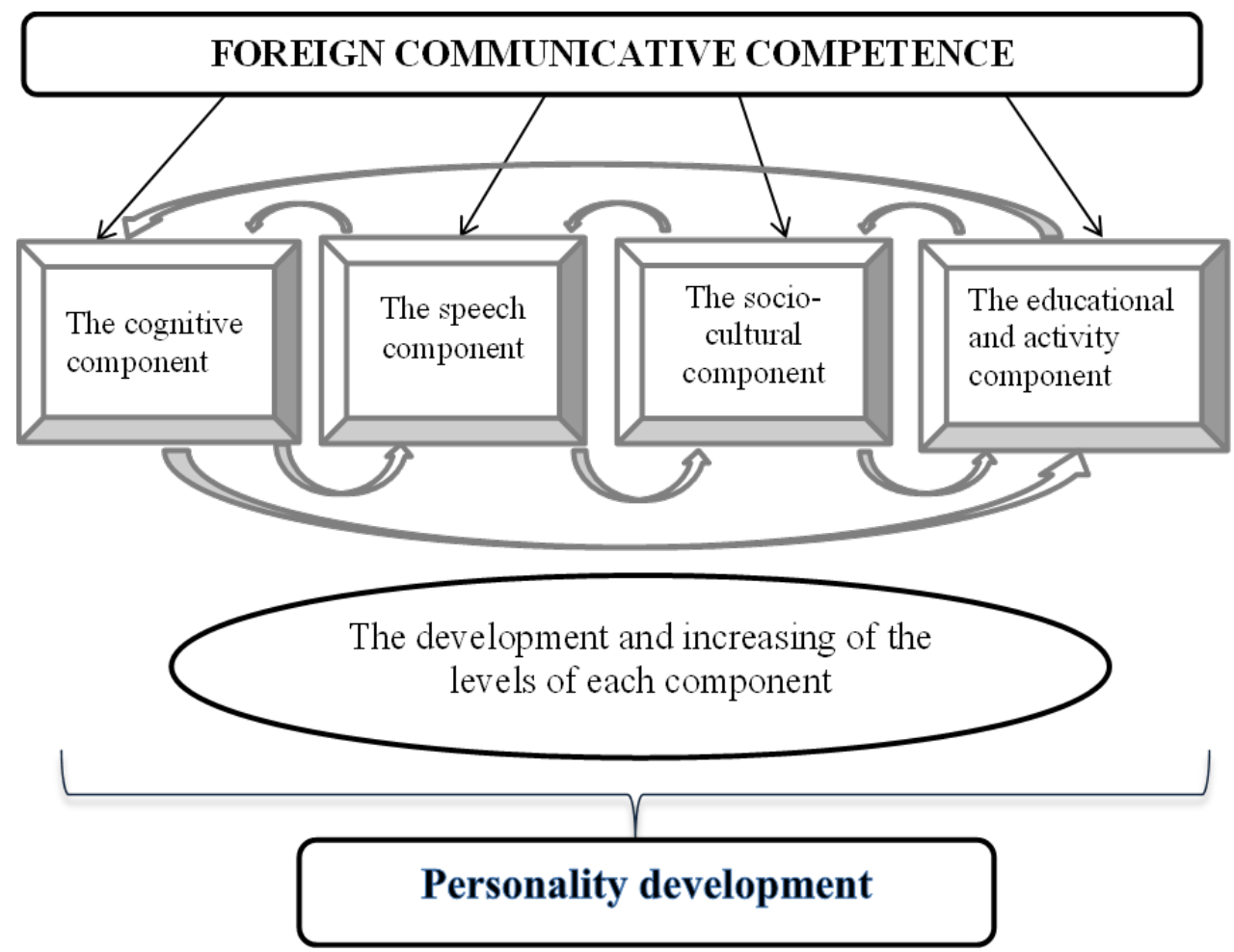

Figure 1 The model of person's communicative competence during the mastering a foreign language (Chykhantsova, 2019)

We offered to students in the college to complete some foreign language tasks during their studying that included reading, listening and grammar assignments. These tasks determined the quality and effectiveness of foreign language proficiency, as the average coefficients of performance and quality factor. And these tasks enable us to analyze students' level of foreign language learning. The relationship between the coefficient of performance and the level of quality of knowledge are distributed as follows: from 1 to 0.9 - high level; from 0.8 to 0.7 - sufficient level; from 0.6 to 0.5 - average; 0.4 and below - elementary level (EPFL, 2017).

We can conclude that the college students have an average level of foreign language skills based on the data obtained (Table 1).

Table 1 Indicators of students' foreign language mastery (Chykhantsova, 2019)

\begin{tabular}{|c|c|c|}
\hline $\begin{array}{c}\text { Average mark in a foreign } \\
\text { language }\end{array}$ & $\begin{array}{c}\text { The coefficient of knowledge } \\
\text { efficiency }\end{array}$ & $\begin{array}{c}\text { The coefficient of } \\
\text { knowledge quality }\end{array}$ \\
\hline 7.56 & 0.63 & 0.54 \\
\hline
\end{tabular}

Source: Inshomovna komunikativna kompetentnist' jak faktor rozvitku osobistosti. Aktual'ni problemi psihologiï: Zbirnik naukovih prac' Institutu psihologii imeni G.S. Kostjuka NAPN Ukrainy, 16, 279-286.

$n=84$ 
Unfortunately, the coefficient of performance and the quality of knowledge of the respondents testified to the average level (from 0.6 to 0.5 ) of their foreign language skills.

Thus, it is revealed from the answers of students (45.7\%) that the reason that prevents them to speak a foreign language freely is a psychological factor. This factor depends on the character of the person. We obtained this information using our own questionnaires. If a student is shy and lacks confidence, these qualities will interfere with his or her foreign language. It was also found that students do not experience excitement when speaking foreign languages when their language skills are not subject to assessment by the teacher or classmates. This was stated by $83.5 \%$ of the respondents.

The results of our survey demonstrate that the majority of college students (63.8\%) believe that self-esteem determines relationships with others, criticality, demanding self and attitude to successes and failures. Self-education involves a certain level of development of intelligence, which is evident in everything related to the change of self for $59.1 \%$ of the respondents. Awareness of one's behavior is exercised through self-observation, introspection and self-criticism.

We offered to college students to provide their own assessment of their knowledge and skills in order to determine the level of formation of foreign language communicative competence (Fig. 2). We believe that self-esteem directly influences on self-assessment. In this case, the assessment of students compared with the expert assessment.

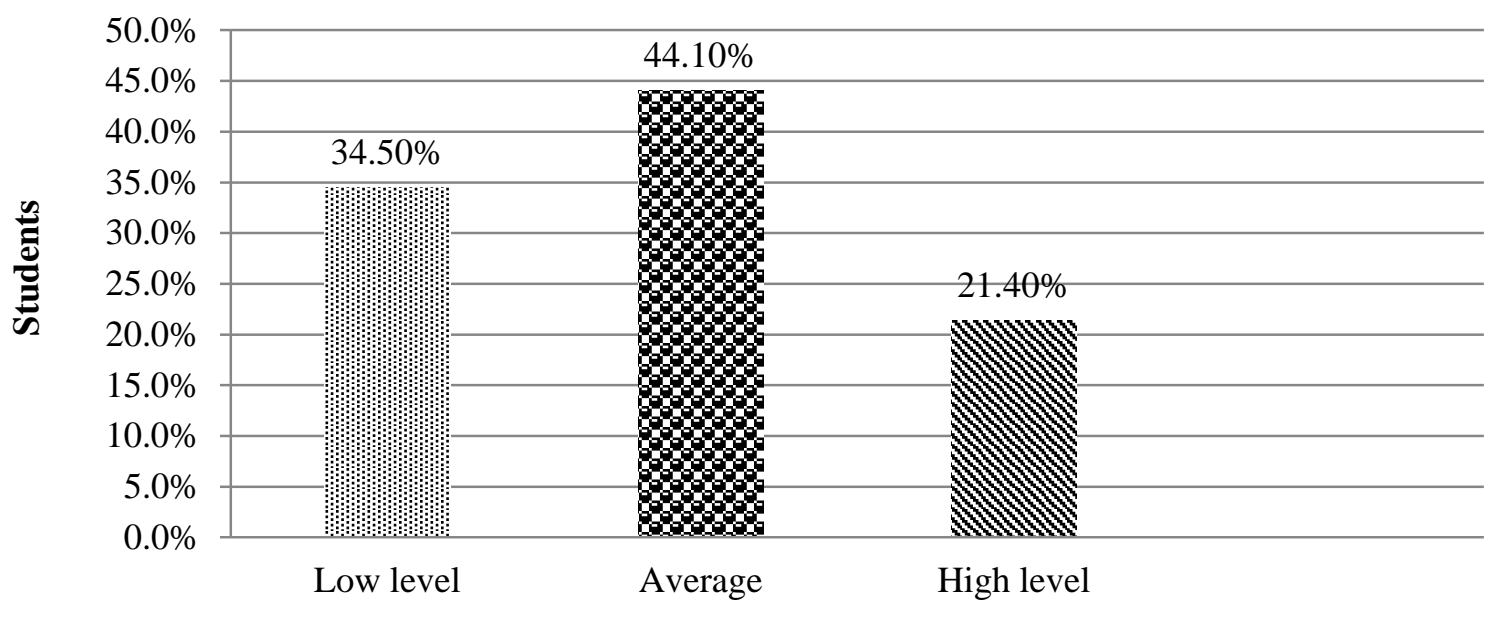

Figure 2 College students' assessment in foreign language communication

Comparative analysis of students' self-assessment and experts' estimates demonstrate that in most cases, students (44.1\%) exceed the average level of assessment of communicative knowledge and skills. Such data can be explained by the students' lack of experience in speaking foreign languages and using them 
in real situations. The low self-esteem of students (34.5\%) is explained by the high self-criticism and demanding of their own level of development of foreign language knowledge and skills. Most respondents have low and medium levels of self-esteem during language communication, as our survey results show.

The respondents made themselves a significant contribution to the development of foreign language communication competence through personal development, which implies an increase in their own self-esteem and self-control. Studying and forming self-control in students helped them to develop an adequate self-assessment of their foreign language communication activity. We are convinced that mastering a foreign language communication requires the students to develop a certain level of communication competence, which is realized with the help of speaking skills. These skills are developed on the basis of linguistic, national and language skills.

We also investigated the levels of development of respondents' foreign language communicative competence components in order to influence the personality development process. The results of the empirical study are presented in table 2.

Table 2 The components levels of foreign language communicative competence (Chykhantsova, 2019)

\begin{tabular}{|l|c|}
\hline $\begin{array}{c}\text { Components of foreign language } \\
\text { communicative competence }\end{array}$ & $\begin{array}{c}\text { Levels } \\
\text { (12-mark average) }\end{array}$ \\
\hline Communicative & 7.8 \\
\hline Speech & 6.9 \\
\hline Socio-cultural & 5.4 \\
\hline Educational and activity & 5.2 \\
\hline
\end{tabular}

The ratios between the components are distributed as follows: from 1 to 4 points - low level; from 5 to 9 points - average level; from 10 to 12 - high level (EPFL, 2017). The reliability of the quantitative data obtained was consistent with the results of our observations. Educational and activity (5.2) and socio-cultural (5.4) components of foreign language communicative competence were less developed. These data indicate the need for college students to put their knowledge into practice and to communicate with native speakers.

We can conclude that the respondents have an average level of development of all components of foreign language communicative competence. Such average indicators can be explained by the fact that during the learning and mastering of foreign languages students' attention is paid to only some components of communicative competence. This means that students need to develop at the same time all four components of foreign communicative competence: the cognitive component, the speech component, the socio-cultural component, the educational 
and activity component. And this affects the development of the personality as it is presented on the Figure 1.

\section{Conclusions and discussion}

Developing the technology of studying above competence, we have met a number of requirements that would stimulate a person's need for foreign language communication: trust in communication, relaxation in communicative actions, the ability to listen to the interlocutor, sympathy and mutual support in communicative atmosphere, providing psychologically trust, emotional wellbeing, confidence in one's abilities and opportunities.

The results of the study allowed us to establish the psychological specificity of the process of mastering a foreign language. We have developed the structural model of foreign language communicative competence. It is the basis for defining a system of exercises and tasks that can provide the formation of a particular competence in a person as a macro object and its structural components.

In the study we determined that foreign language communication competence is an integrative personality formation, which has a complex structure and emerges as the interaction and interpenetration of cognitive, speech, sociocultural and educational-activity components, the degree of formation allows to exert language communication. The results of our study confirm our view that foreign language communication competence is an effective means of personality formation. This type of competence promotes the development of personality traits, increases the level of interest in mastering a foreign language, allows to engage not only the personality consciousness, but also its feelings and emotions.

Therefore, foreign or intercultural communicative competence is not only an external system of signs, which serves for communication, but also as an integral property of the individual, his/her mental and psychophysiological function and his/her activity. It follows that foreign language speech influences the formation and development of the personality.

\section{References}

Bolster, A., \& Balandier-Brown, P. (2004). Young learners of modern foreign languages and their transition to the secondary phase: a lost opportunity? Language Learning Journal, 30, 35-41.

Boretska, G.E. (2010). Suchasni tehnologiï formuvannja anglomovnoï kompetenciï v govorinni v uchniv osnovnoï i starshoï shkoli. Inozemni movi, 2, 23-26.

Byram, M., Gribkova, B., \& Starkey, H. (2002). Developing the intercultural dimension in language teaching. Language Policy Division Directorate of School, Out-of-School and Higher Education. DGIV Council of Europe, Strasbourg. 
Chyhantsova, O. (2014). Foreign language learning of students with non-linguistic speciality. International Scientific Journal “Euro-American scientific cooperation”, 5, 103-109.

Chykhantsova, O. (2019). Inshomovna komunikativna kompetentnist' jak faktor rozvitku osobistosti. Aktual'ni problemi psihologii: Zbirnik naukovih prac' Institutu psihologii imeni G.S. Kostjuka NAPN Ukrainy, 16, 279-286.

Drăghicescua, L.M, Cristeab, S., Petrescua, A.M, Gorghiuc, G., \& Gorghiud, L.M. (2015). The Learning to Learn Competence - Guarantor of Personal Development. Procedia - Social and Behavioral Sciences, 191, 2487-2493.

Educational programms of foreign languages. (2017). [Data file10.01.2020]. Retrieved from https://osvita.ua/doc/files/news/589/58921/inozemni-movi-10-11-19_09_2017.pdf

Feuerstein, R., Feuerstein, R.S., Falik, L., \& Rand, Y. (2006). Creating and enhancing cognitive modifiability: The Feuerstein Instrumental Enrichment Program. ICELP Publications.

Harmer, J. (2012). The Practice of English Language Teaching. England, Pearson Education Limited.

Kozyreva, O., Sagaidak-Nikituk, R., \& Demchenko, N. (2017). Analysis of the socio-economic development of Ukrainian regions. Baltic Journal of Economic Studies, 3(2), 51-58.

Menke, M.R., \& Paesani, K. (2019). Analysing foreign language instructional materials through the lens of the multiliteracies framework. Language, Culture and Curriculum, 32, 34-49. DOI: http://dx.doi.org/10.1080/07908318.2018.1461898

Onufrieva, I.L., \& Onufrieva, L.A. (2010). Psihologichnij aspekt navchannja inshomovnogo movlennja doroslih. Problemi suchasnoï psihologiï, 7, 496-507.

Petrie, G.M., \& Avery, L. (2011). Identifying our approaches to language learning technologies: improving professional development. English Teaching Forum, 49(3), 2-17.

Saenko, N.S. (2010). Navchannja inozemnoï movi studentiv nemovnih special'nostej na osnovi osobistisno-dijal'nisnogo pidhodu. Visnik NTUU «KPI». Filosofija. Psihologija. Pedagogika, 1, 224-228.

Serdiuk, L.Z. (Ed.). (2018). Psihologichni tehnologiï samodeterminacii rozvitku osobistosti: monografija. Institut psihologiï imeni G.S. Kostjuka NAPN Ukrainy, Kyiv. [Data file 10.01.2020]. Retrieved from http://lib.iitta.gov.ua/id/eprint/712878

Tomchuk, M.I., \& Buchac'ka, S.M. (2010). Psihologichna gotovnist' majbutnih fahivciv do dilovogo spilkuvannja inozemnimi movami: monografija. Vinnicja, Vinnic'ka gazeta.

Ukrainian English language teacher learning platform. (2020). British Council, Cambridge Assessment English, Cambridge University Press. [Data file10.01.2020]. Retrieved from https://nus-english.com.ua/en/for-teacher

Volobueva, O. (2012). Sprijnjattja ta rozuminnja tekstiv inozemnoju movoju. Visnik Kï̈vs'kogo nacional'nogo universitetu imeni Tarasa Shevchenka. Vijs'kovo-special'ni nauki, 29, 2023. Retrieved from http://nbuv.gov.ua/UJRN/VKNU_vsn_2012_29_7 